\title{
Halted Democracy: Government Hijacking of the New Opposition in Azerbaijan
}

\section{Altay Goyushov and Ilkin Huseynli}

The unprecedented government crackdown against its critics started on the eve of the 2013 presidential elections which effectively halted the democratization process and caused a general pessimism in the society. Despite the high level of youth activism, Ilham Aliyev won a third term as president in 2013. In addition to the defeat of the opposition, since then, the government of Azerbaijan has become more authoritarian and the political sphere of the opposition has successfully been narrowed down to social media. However, due to the misguided view that anything other than the defeat of the ruling party should be considered a failure for the opponents of the government, achievements of the youth activism in Azerbaijan between 2005 and 2013 have been overlooked while their contributions to the Azerbaijani society have been ignored. This article examines the activities of the independent youth organizations in the country, which emerged after the serious setback of the opposition political parties in the 2005 parliamentary elections.

Two events had caused a heated political debate among the opponents of the government concerning the reasons of their failures. First, in 2003, after the death of the then president Heydar Aliyev, the opposition had a good chance to grasp the power. But due to the falsification of the electoral results as well as the oppression of the protests, Ilham Aliyev managed to succeed his father.

Second, after two years, the Azerbaijani united opposition, influenced by the then recent revolutions in Georgia and Ukraine, failed to galvanize the masses behind itself and lost the parliamentary elections to the ruling party. After these unsuccessful attempts of changing the government, the oppositionminded people, including some writers, journalists, lawyers, and public figures,

\author{
A. Goyushov $(\bowtie) \cdot$ I. Huseynli \\ Baku Research Institute, Baku, Azerbaijan \\ E-Mail: altay.goyushov@fulbrightmail.org
}

(C) Springer Fachmedien Wiesbaden GmbH, ein Teil von Springer Nature 2019 
questioned the strategy of the traditional opposition parties, namely Musavat and the Azerbaijani Popular Front Party (APFP), by arguing that apart from the oppressive nature of the government other reasons contributed to the failure of democratization as well.

Many of them argued that traditions and habits of Azerbaijanis, such as patriarchal values, enabled the government to manipulate the elections and to legitimize authoritarianism. Some others blamed the traditional opposition for lacking clarity in their ideas and messages of change and casted doubts on loyalty of traditional opposition to basic principles of liberal democracy. They also criticized the leading figures of traditional opposition for failure to lead by example in regard of their personal integrity and thus to convince the public that they are somehow different from their rivals in the government. So, for this emerging trend along with outdated traditions the old opposition was regarded as populist and as another bulwark of ideas and habits hindering modernization. In their turn, the traditional opposition continued to insist that the only obstacle to democratization remains the oppressive nature of the government rather than the traditions of the Azerbaijani people.

In other words, while the first group or what we call the new opposition insisted that some outdated traditions of the Azerbaijani society as well as the inability of traditional opposition parties were among the important reasons of failing democratization, the second group, that is the traditional opposition, maintained its view that the people supported democracy and it was the victim of the authoritarian government.

While the traditional opposition refers to the Musavat Party and the APPF, which were in power for a year till 1993, the new opposition needs to be clarified. By new opposition we mean independent organizations established by writers, students, and social activist in order to educate the public and create a new sphere for public debates. In the length of this article, we cover the activities of Azad Yazarlar Ocă̆ (AYO-Union of Independent Writers), AN Network (AN şəbəkəsi) and its project Kapellhaus Lectures, OL! Azerbaijani Youth Movement and its project Azad Fikir Universiteti (AFU-Free Thought University), Dalğa Movement, and Nida Civic Movement. We discuss the different strategies of these youth organizations and trace their effects till today. Other than the abovementioned independent youth organizations, we also discuss how the government tried to hijack this idea by creating its own conservative and pro-government youth organization Irali Public Union of which name is taken from the campaign slogan of Ilham Aliyev (Ilhamla irali-forward with Ilham). While the new opposition focused on topics such as democratic institutions, free speech, social justice, societal pressures on the youth, religion, sexuality, gender, and 
to some extent political theories, the pro-government organizations preferred to stay within the boundaries of Azerbaijani conservativism and instead of debating taboos, they focused on patriotism, militarism, solidarity, achievements of Heydar Aliyev and Ilham Aliyev, business opportunities for the youth, organizing art galleries, and at best, mild criticism of Azerbaijani society and in some rare instances the government policies.

In this article, we argue that while the new opposition between 2005 and 2013 did not realized all the goals set, it influenced a new generation of young activists who became the loudest supporters of democratic and secular values in Azerbaijan. This grassroots activation of the youth brought noticeable changes to some parts of the Azerbaijani society by questioning the authority of traditional values. Many young people, especially students found a platform to discuss their problems concerning everyday basic issues such as intimate relationships as well as their freedom to live in accordance with their personal choices and desires without the family interference in the light of theoretical questions such as the importance of liberal democratic values, individual liberties, and the rule of law. The successfully established connections between material problems and transcendental ideals encouraged some young people to participate in the open discussions and seminars organized by the new opposition. Because of the emergence of this new generation of active youth, the government was forced to incorporate some elements of this new discourse at least by making some cosmetic changes within its structures. The government became successful in its attempts of weakening the new opposition by hijacking its ideas and creating similar but pro-government organizations; neutralizing or "buying" some well-known opposition figures such as writers and journalists; and finally, persecuting the leading members of the youth organizations.

In the following sections, first, we give a background of the political developments in Azerbaijan since the year 2005 when the unified traditional opposition tried to challenge the government in legislative elections. Second, we give a descriptive account of the emergence of youth organizations and the rationale behind the activism of the then new generation between 2005 and 2013 mainly based on our interviews with key public figures. ${ }^{1}$ Then we discuss the reaction of the government to these new developments and the attempt of the ruling elite to hijack and transform the discourses of the new opposition by various methods. Finally, we discuss the positive effects of the new opposition on the Azerbaijani society as well as its shortcomings.

\footnotetext{
${ }^{1}$ In the preparation of this article, we greatly appreciate the contributions of Ali S. Novruzov and Rashadat Akhundov.
} 


\section{Political Developments}

In 2005 two main opposition parties namely Musavat and the APFP put their long rivalry aside and by uniting almost all opposition forces behind them entered the parliamentary elections with their main competitor being the ruling Yeni Azarbaycan (YAP-New Azerbaijan) party. However, their bid once more was lost due to failure to mobilize enough public support to oppose falsification of elections by ruling regime (Kassa 2012). In general, it was a serious blow to traditional opposition parties which were primary forces opposing the further consolidation of authoritarianism in Azerbaijan. And as a result of this, in 2008, the weakened and effectively sidelined traditional opposition parties boycotted the presidential elections citing the longstanding obstacles and the lack of necessary conditions for free and fair elections (Isler Beguin 2008). In addition to its suffering from heavy-handed rule of Aliyev's power and material disadvantages, the traditional opposition entered a prolonged stage of ideological bankruptcy. As Thomas de Wall, Senior Fellow at Carnegie Europe, pointed out "The old, main Azerbaijani opposition parties, Musavat and the [Popular] Front, which briefly governed the country in 1992-93, have little to offer the public and live off past glories. Indeed, for President Aliyev they are a useful contrast to his own regime, which, the public has been told, may have deviated from democracy but has brought prosperity and stability instead" (de Waal 2018).

Emerged in late 1980s and seizing power in 1992 for one-year rule of the country the APFP and Musavat were undoubtedly more democratic in comparison with their main opponent - the ruling YAP, which established and run by old soviet elite. However, dubbed as "national democrats" and dominated mainly by ethno-nationalist forces, these two opposition parties stagnated and subsequently lost their ideological as well as intellectual superiority over the ruling YAP, which transformed itself into a new style nationalist organization. Dominated by old soviet guard, YAP gradually acquired the nationalistic tone of its rivals, that is, those two oppositional parties, and effectively sidelined them in this discourse. The ruling party emerged even more progressive in comparison with the opposition in terms of its ideology due to the replacement of chauvinistic ethno-nationalism of the latter with state-civic nationalism. In this regard, the only remained point of these oppositional forces in which they still had higher moral voice was their appeal to democratization. Yet, neither of them was particularly democratic in organizational or ideological terms. As a result, they had been struggling to win the public support for their cause. 
In its turn, the ruling party, triumphed and emboldened by flowing into the country billions of oil money, did not stop after "winning" presidential elections in 2008 and planned a referendum for the next year, which would lift the two term limit for the then incumbent Aliyev to run for the third time. In the course of preparation for the referendum, the government shut down broadcasting of VOA, RFE/RL, and BBC Azeri on FM waves, which were the last remnants of independent information sources within the country (BBG 2018). By then, TV stations had already been under complete monopoly of the ruling regime. Independent and oppositional print media were crippled due to the longstanding pressure of the government and they barely existed with remaining couple of outlets having very small circulation (Democracy Monitor 2007). As a result, nearly unchallenged monopoly and control over the flow of information was established by the government. Almost no space left for the opposition parties to discuss and express their opinions on the referendum. Therefore, while meeting little resistance from public and opposition, the government crossed another milestone in the transformation of the country into the consolidated authoritarianism. The referendum in 2009 paved the way for Ilham Aliyev to be elected the head of state for the third time in a row.

However, then in late 2009 and early 2010, a dramatic turn of events due to the mainly three developments in both world and local stage caused serious problems for the government to proceed with its plans and forced the elite to resort to the unprecedented and internationally well-documented repressions (Amnesty International 2015; IMS 2015; HRW 2016). These events, which challenged the authoritarian rule, were popularization of social networks; activities of various youth organizations entering public and political life of the country; and the Arab Spring, which seriously frightened the government. Although eventually the government was successful in implementation of its plans and halted the democratization process (at least for the time being) with its heavy-handed response, it still suffered from significant setbacks, too. Repressions turned the attention of worldwide media and human rights organizations to the increasingly oppressive nature of the regime and its corrupt dealings. Sensible for its image abroad Azerbaijani ruling elite was frustrated due to this extensive of coverage of its repressions and corruption.

Since the late 2009 early 2010 Facebook, by becoming the most powerful social platform in the country, opened a free space for public discussions. Since the mainstream media outlets are under the control of the government, only social media give opportunity for opposition-minded individuals to speak their mind. 
In this respect, social media, especially Facebook is crucial for the critics of the government in terms of visibility and popularity; however, the benefits "also increases the likelihood of repercussions" (Pearce and Guliyev 2015, p. 239). Increased visibility makes it easy for the authorities to identify oppositionists. For example, many of our interlocutors stated that dozens of ordinary citizens have been detained for a few days because of Facebook posts or "likes." These individuals, nevertheless, fear from publicize this information due to further persecutions by the government. Despite all their disadvantages, social media remain the only alternative source of information for oppositionists. Thanks to social media, the government lost monopoly over the flow of information and discussions, and easily became the target of widening public criticism. This social network seriously undermined the government propaganda and worsened its acceptance by the general public. Public statements of local officials and deputies became frequent targets and were ridiculed by these new active voices. The Azerbaijani authoritarian regime, which usually relays on fear and its exalted authority as its main tools to maintain power, started rapidly losing both.

Then entrance of a new segment of society, namely the youth organizations, into public and political life caught the government unprepared. The government had a decade long experience in dealing with its old rivals, that is, the traditional opposition. However, the critical voices of newly galvanized youth challenged the government with new discourses, different set of values and methods. This was the voice of the emerging social middle class. For a long period of time, the opposition in Azerbaijan was associated with poverty due to the longstanding pressure of the government on public employees and private business to deny any contacts with the political opposition. While economic middle class, namely mid-level business, still tried to distant themselves form any kind of expression of discontent due to the fear of the government new mid-level, well-educated (often abroad) career professionals, on the contrary, became the face of newly emerging dissent and dissatisfaction. The government was caught completely off guard to face these new developments. The Republican Alternative civic movement $(\operatorname{ReAl})$, recently became a party, emerged as the first established political group representing this new style opposition.

At last, Arab Spring of 2010 further fomented birth of new critical voices. The government, fearful of the events in Arab countries, introduced cosmetic plans to fight corruption. Ideas like ASAN Service, which significantly reduced mid-level corruption in various areas, were the first genuine responses of the government to these newly emerged existential threats to its unchallenged monopoly of power. Nevertheless, in 2010, the government still continued its plan to build a managed democracy. The parliamentary elections were held in the same year left the local 
legislative body without a single member of real opposition for the first time since 1990 (Heinrich 2011, p. 5). Yet activism of youth was still growing and continuing to mobilize more young people to public life.

Then in early 2013 these new dynamics of the society found a chance to express themselves in an opposition to the politics of the governments. The death of a young conscript soldier in a non-combat situation and his photos shared on social network caused public outrage and a mass unauthorized protest in downtown Baku was organized by youth activists. The government's response to this activism was a large scale, unprecedented major crackdown launched against political opponents, civil society leaders, heads of local NGOs, and prominent human rights activists. In addition, prominent international donors were forced out of the country, legislation on donor's activities was tightened, and criminal investigations against them were launched. Hundreds were arrested and jailed, many left the country. The same year President Aliyev was reelected for a third term in a criticized by the international community elections (OSCE 2013).

The crackdown effectively halted the possible democratization process. However, repressions were not the only response of the government. Confronted by a youth activism, the government employed various tactics to engage the former and to divert it from political involvement. Repeating the models and discourses in which youth activism were expressed while transforming their content were among the most eye-catching practices adopted by the authorities. Despite overall failure of democratization in Azerbaijan, youth activism did introduce some significant and visible changes to Azerbaijani society. Moreover, in some instances, it forced the government to retract from its previous positions and took notice from public concerns. So the impact of this youth activism on the transformation of the society will be discussed further as the main point of this article.

\section{Rise of the New Opposition}

Failure of the opposition forces first in the 2003 presidential and then the 2005 parliamentary elections made some especially foreign-educated Azerbaijani young people and new generation public figures arrive at the conclusion that the first and foremost challenge is to question the traditional values of the population in order to promote democracy among the masses. For it was clear that the vast majority of Azerbaijanis was quite conservative in their lifestyle and beliefs. Under these circumstances, from this point of view, how could a reasonable person expect any democratic changes in the government of the country? In short, Azerbaijanis were not democratic in their daily lives and in their attitudes; so, 
why not change the people first? With this reasoning in mind, a few organizations were established with the goal of educating the Azerbaijani citizens and promoting liberal-democratic values in the society.

One of the most important developments was the establishment of AYO led by Rasim Garaja, Azad Yashar, Hamid Herischi, and Murad Kohnagala (Garaja 2018, p. 152). Although AYO was founded in 2001, it became popular with Alma Newspaper after 2006. The goal of AYO was to give a voice to young writers, also known as the Alatoran (Twilight) group, who rebelled against the establishment writers from the Union of Azerbaijani Writers (Azərbaycan Yazıçılar Birliyi- $A Y B)$ or, what they referred to as "the ministry of literature," an organization founded in Soviet Azerbaijan (Qaraca 2018, p. 162). AYO attracted and popularized young writers such as Seymur Baycan, Ali Akbar, Gunel Movlud, and Akshin Yenisey. By fearlessly lynching the stereotypes and conservative backwardness of the society these young writers introduced new bold language to Azerbaijani literature as well. They raised quite contagious issues such as suppression of sexuality among young people, and, most importantly women by conservative attitudes of the society. Many of our interlocutors stated that AYO writers, especially Seymur Baycan and Ali Akbar heavily influenced their approach to traditional values and helped them to be more open-minded. Almost all of our interlocutors pointed out that they were conservative and nationalists in their early twenties but also by reading writers such as Baycan and Akbar they softened their positions on many issues and embraced many liberal values. In this regard, AYO members became liberal educators of the youth; they initiated critical approach and launched genuine a transformation process.

While it is extremely difficult to say how many people were affected by their writings, a reasonable guess, based on our interviews with Garaja, Baycan, Akbar, and many other social activists, can be around ten-fifteen thousand. It should be noted that these writers were popular in a narrow circle and they influenced a portion of young people, mainly in Baku. Alatoran Journal (2004-2012) issued 18 volumes and the circulation of each volume was around 500-1000. Rafig Tagi, one of the most popular and controversial members of AYO, was well-known for his sharp language and criticism of religion. He was arrested with the changes of inciting hatred for three years in 2006 but was released after a few months with presidential pardon. However, on 21 November, 2011 he was assassinated and died in a hospital after a few days (RWB 2011). In his autobiography, Rasim Garaja argues that with his assassination, many AYO members did not want to be associated with Tagi and AYO anymore. As a result, in its tenth year, AYO was dissolved (Garaja 2018, p. 182). 
In 2005, some groups of educated Azeri youth started to show the early signs of civic activity. One of these groups was Alumni Network-later referred to simply as AN Network, consisted of a few public figures such as Emin Milli, Khadija Ismayil, Rashad Shirin, Erkin Gadirli, and others. The idea of this group consisting of individuals who mostly studied abroad, was that networking was better than hierarchical organization because while the latter could easily be destroyed if the government persecuted its leaders, the former lacks any hierarchical structure and therefore cannot be intimidated by the arrests of a few people. The Friedrich Naumann Stiftung under the direction of Arastun Orujlu, the country representative for Azerbaijan were organizing series of seminars on liberty, liberalism, and libertarianism where prominent libertarians and adherents of Austrian school such as Tom G. Palmer and Hans-Hermann Hoppe delivered lectures to select groups of Azerbaijani youth leaders. According to Ali Novruzov, one of our interlocutors and a member of now defunct OL! Movement, "anarcho-capitalist ideas derived from these seminars might have possibly influenced the thinking of Kapellhaus leaders and their concept of networking instead of organizing." AN Network organized lectures known as Kapellhaus Lectures in German Lutheran church, which was under the auspicious of the German Embassy in Azerbaijan, in downtown Baku.

On every Sunday, well-known public figures including lawyer Erkin Gadirli, culturologist Rahman Badalov, film director Ayaz Salayev, writer Chingiz Abdullayev, political scientist Eldar Namazov, composer Elmir Mirzoyev, and a few foreign scholars gave lectures to approximately one hundred people, most of whom were students. Lectures and discussions were dynamic and often touched compelling questions, which otherwise would be impossible to discuss in state institutions and universities. The most prominent lecturer, however, was Erkin Gadirli, a then respected law teacher at Baku State University and currently the secretary of foreign relations of ReAl Party, who sometimes attracted over three hundred people and talked about issues such as democracy, liberalism, rule of law, responsible government, and individual liberties, critical thinking and even Derrida's deconstruction in his lectures. As Novruzov stated, many people, including him, attending the lectures either heard about these concepts for the first time in their lives or in case if they might had been familiar with some of these concepts were unaware of the meanings as well as theoretical and practical implications of them. For example, democracy, at best, was understood as a majoritarian system without any consideration to checks and balances, minority rights, and individual liberties. Novruzov pointed out that because the universities did not teach or create any opportunity for students to discuss public issues, 
government policies as well as political theories, students were eager to participate in the Kapellhaus Lectures.

Nevertheless, in 2007 the German Embassy refused to allow the AN Network to use the place for public lectures. In our interview with Erkin Gadirli, he stated that the only logical reason behind this decision was the pressures of the Azerbaijani government on the German Embassy. Many students who participated in the Kapellhaus Lectures started to question the knowledge of their teachers at universities and demanded to discuss issues of public concern. Moreover, lecturers were becoming famous and it concerned the government. Gadirli and our other interlocutors apprised us that the Kapellhaus Lectures was an apropos environment for young people to establish different networks. They stated that the founding members of Dalğa and OL! movements were also among those who regularly participated in these lectures.

Then the first active youth movement called Dalğa appeared on the stage in early 2005. The idea was initiated by a group of students from Azerbaijan State University of Economics (ASUE) with the purpose of promoting democratic values, civility, tolerance, and rule of law. The Declaration of the movement states that Dalğa "strongly rejects any kind of discrimination [and] believes in the importance of reevaluating all values that restrict freedom" (Dalğa 2005). According to our interlocutors, the first members of Dalğa were the students of Khagani Hass, an influential anarchist teacher at ASUE. The movement attracted attentions by extravagant public events such as walking barefoot in downtown Baku. Furthermore, since the movement emphasized the necessity of selfreflection and questioning the authority of traditions, its members became (in) famous for radically challenging the taboos of the society. They were advocating free love, which was and still is unacceptable for a conservative Azerbaijani society. In this regard, while Dalğa gave a voice to some individuals, they only managed to promote these libertarian values in a narrow circle of young people. There are allegations that after a few years of its establishment, Asim Mollazade, a progovernment party leader and MP, gained ascendancy over the movement. According to our interlocutors, moderate activities of Dalğa after 2008 strengthened the credibility of these allegations.

In less than two weeks' aftermath of the 2005 elections, on 17 November, eleven young friends discussed the possibility of establishing a new organization because they felt obliged to contribute to their society. After a week, they set the goals of this hypothetical organization, which were to change the society by education, help young people to acquire democratic principles and learn about new ideas as well as to support the youth in their personal development (Salamli 2009). After a few months, on February 11, 2006 a new independent youth 
movement OL! (Be!) was founded by twenty two friends. Quite interestingly, about half of the founding members were women, a rare characteristic of organizations in Azerbaijan. Some of the founding members studied abroad, grew up in intellectual and opposition-minded families. For instance, Turgut and Ilkin brothers were the sons of Isa Gambar, former acting president of Azerbaijan and the chairman of Musavat Party, and Vugar Salamli was their close relative; Adnan Hajizade's father Hikmat Hajizade (PhD in physics) was the member of Musavat and the first ambassador of Azerbaijan to Russia between 1992 and 1993; Ruslan Asadov, Rashadat Akhundov, and Ilkin Alisoy were also the sons of oppositionminded individuals.

The three major principles of OL! were non-violence, tolerance, and modernity. In order not be persecuted by the government, from the beginning, the movement made clear that its aim was educative and it did not want to be affiliated with any political party (OL! FAQ 2006). If we take into consideration the frequent government persecutions and unsolved assassination of Elmar Huseynov, who was the most famous critic of the government and the editor-in-chief of Monitor magazine, in March 2005, this approach of OL! Movement was understandable. Yet, its goal was political, that is, the realization of democracy in Azerbaijan. The Manifesto of the movement, for example, stated that the "active participation of youth in public life is one of the main conditions for building democracy and Civil Society" (OL! Manifesto 2006). As it is seen from the Manifesto of the movement, which promoted free-thinking, democratic values, justice, tolerance, and modernity among the other principles, the aim was to change traditional values of the Azerbaijani society in order to make it more receptive to liberal democratic values. In his blog, Ruslan Asadov, one of the founding members of the movement, summarized the fundamental logic of OL! by simply stating that "it is important for the people to have democratic values for the establishment of democratic institutions" (Asadov 2009).

During our interview with Rashadat Akhundov, another founding member of OL!, who would later leave the movement to create political Nida Civic Movement, he emphasized three reasons behind the policy of non-engagement in politics. First, he stated that after the repressions of the opposition members, the best option for a newly created organization was to remain neutral in politics because even after the election of 2005, there was a serious threat to the government critics. Second, OL! members believed that since they start from the scratch, they do not have to choose any side. Third, from the early experiences of the failures of the opposition, OL! members were convinced that quality is more important that quantity and in order to create a strong civil society with firm democratic values, any serious organization had to educate the youth. This emphasis on the quality 
can be seen in the membership procedures of the movement. Unlike other civic organizations, anybody could not be a member of OL! because the members believed that it was crucial for them to know "the applicant" for some time and be sure that that person share the values of the movement. Only with the recommendations from a significant number of the existing members, a person could be accepted to the movement. Therefore, Akhundov added, "OL! was a club of a narrow circle rather than a youth movement," and as a result of this strict membership procedures, "I consider OL! the best and the most beneficial youth organization in the country."

Between 2007 and 2009, OL! organized weekly lectures in the office of American Alumni Association concerning variety of subjects such as shortcomings of education in Azerbaijan, democratic values, and the role of European Institutions in the transitional democracies. The lectures were popular among the Azeri youth and approximately a hundred people participated in each of them. In the early years, Yahoo groups were the main source for online communication among social activists in Azerbaijan and along with these groups, OL! members were also using their blogs, Facebook, and YouTube to spread their message.

Until 2008, young social activists tried to establish a dialogue with the government bodies. For example, AN Network successfully persuaded the government to create a state scholarship program for young Azerbaijanis to study abroad. They gave a reference to the Democratic Republic of Azerbaijan (1918-1920) which, despite its financial challenges, sent a hundred students to study abroad. As a result of these activities, the state scholarship program was approved in 2007 and continued to benefit hundreds of young people till 2015. However, as Ali Novruzov highlighted in our interview, two events in the first half of 2008 "burned all bridges between the youth activism and the government." First of these events was a terror attack by a Georgian citizen of Azerbaijani descent at the Azerbaijani State Oil Academy (ASOA) on 30 April, 2008. After the shooting which left 13 people dead and 10 people injured, the government did neither declare a national day of mourning, nor cancel the Flower Day, a national holiday on 10 May celebrating the birthday of the late president Heydar Aliyev-the father of the incumbent president (Mehtiyeva 2009). After less than two weeks of the terror act in central Baku, while the government was celebrating the Flower Day, some social activists and bloggers wanted to place red carnations, the symbol of mourning in Azerbaijan, in front of the ASOA. However, they were stopped and detained without any explanation (OL! Media 2009; OL! Blog 2009). This approach of the government was perceived as a lack of respect to the victims of the terrorist act and severely damaged any opportunity for future cooperation between the civil society, particularly the youth organizations and the authorities. 
The second and the most important case was the arrest of two video bloggers, Emin Milli and Adnan Hajizade. Milli had created first online TV (AN TV) in Azerbaijan. He had approximately three thousand followers in Facebook and each of his videos in YouTube had up to a thousand viewers. Milli organized a demonstration with around two hundred people in front of the UN Headquarter in New York against the constitutional changes in Azerbaijan. In addition, he met with German MPs and criticized the Azerbaijani government for its anti-democratic actions. On the other hand, in one satirical YouTube video, mocking the government purchase of 34 donkeys for about 180,000 US\$ from Europe, Adnan Hajizade depicted a "German donkey" which was grateful to Azerbaijanis for their warm welcome. In the press conference, donkey-costumed Hajizade explains to journalists that unlike Europe, Azerbaijan provides more opportunities to donkeys because in Azerbaijan you can achieve everything just by being a donkey (OL! Media 2008). After a week, Adnan and Emin Milli were attacked in a restaurant. They reported the attack to the police but instead they were arrested with hooliganism charges and later sentenced to imprisonment for two and two and a half years, accordingly (IRFS 2009; ESI 2011, p. 16-24). In our interview, investigative journalist Khadija Ismayil stated that Milli was arrested because of his activism abroad; however, Hajizade was not very popular and the only logical explanation is that the authorities believed that the "donkey" in the video satirized President Ilham Aliyev. Although it was a satirical video mildly criticizing the government, Rashadat Akhundov told us in an interview, the government perceived this satire as a threat. He added that Adnan and Emin were not opposition leaders but they could become one in the future; they were undermining the symbolic legitimacy of the government by criticizing the traditional values, which the Azerbaijani authorities often use to justify their actions (see also Milli 2009).

The arrest of two social activists also influenced other youth outside OL! and AN Network. One of the groups that abated its political activities due to the expected persecution of its members was Müsbət Doyişiklik (Positive Change), a political campaign team of Bakhtiyar Hajiyev in the 2010 parliamentary elections. In an email correspondence, Hajiyev wrote that the volunteers of his campaign team were forced either to join pro-government İrəli Youth Movement or they would face persecution like Hajizade and Milli. In order to avoid this outcome and appease the fears of young activists, he chose to educate young people and promote critical thinking among them. Nevertheless, Hajiyev was arrested for two years in March 2011 but conditionally released after a year.

Despite the arrest of one of their crucial figures, OL! Movement continued its usual activities. As a logical consequence of the activities aimed at creating an alternative space for students and all young citizens to discuss the issues of 
public concern, OL! Movement launched Free Thought University (AFU) in October, 2009. To some extent, AFU became a game changer in the society and in a very short period of time gained enormous success and popularity among the youth. Indeed, it was an enlightening mission to educate the youth about issues such as democratic values, civil and minority rights, freedom of expression, gender issues, and others. Moreover, the youth was acquainted with a new generation of public figures, including Hikmat Hajizade, Aghalar Mammadov, Gubad Ibadoglu, Eldar Namazov, Erkin Gadirli, Ilgar Mammadov, and Khadija Ismayil, who otherwise were denied access to the government-controlled media outlets for political reasons as well as internationally renowned figures such as Princeton Professor Michael A. Reynolds, journalist Thomas de Wall, employees of the US Smithsonian Museum, and the United States Ambassador to Azerbaijan Matthew James Bryza (AFU 2013). AFU organized interactive discussions, lectures or seminars twice a week about democracy, freedom, rule of law, political ideologies, journalism, Arab Spring among many others. Until its closure by the government in April, 2013, AFU held over three hundred events with participation of more than four thousand people (Muradova 2013).

During our interview with Vugar Salamli, he highlighted that although OL! Movement and its project AFU were not affiliated with any political organization, the Azerbaijani authorities perceived them as a threat. In this respect, he continued, it became clear that even a "free university" constituted a threat for the government. The reason behind the closure of AFU, Salamli and Akhundov pointed out, might be the assumption that many young people became active in some social as well as political organizations such as Dalğa, Nida and ReAl. In a way, the government perceived AFU as a recruitment tool for the opposition groups.

The youth movements became popular for many reasons. First, the continuing failure of traditional opposition parties and their ideological bankruptcy increased the popularity of the youth movements. These opposition parties did not make any changes in the leaderships or ideologies. For example, Ali Karimli, who was the deputy chairman of the PFP, succeeded late Elchibey in 2000 and still leads the party. Similarly, Isa Gambar was the chairman of Musavat Party from 1992 until 2014 and he was also succeeded by his deputy chairman Arif Hacili. Still these parties were promoting ethnic nationalism, Turanism, and conservatism. In other words, Azerbaijani opposition political parties were still using the nationalistic language of the late 1980s and early 1990s. However, this old rhetoric was not attractive for those young people who were exposed to various new ideologies through online media, their educational backgrounds, and the social activism of the youth movements in general. 
The second reason was that the youth movements appealed to new social layer, which traditionally had been loyal to the government. This feature distinguished the youth movements from the traditional opposition and contributed to the rising fear of the government. As Francis Fukuyama states when the number of social middle class (educated individuals with a property and an occupational status) is small, that is, less than $30 \%$ of the general population, it supports authoritarianism (Fukuyama 2014, p. 419-420). The social middle class views the masses as a threat which would ultimately demand an economic distribution if seizes the power. Similarly, in Azerbaijan, this social middle class perceived old opposition as a representative of deprived classes which was seeking economic redistribution. As a result of this attitude and fear, the members of this class were either apolitical or supporters of the ruling party. However, on the contrary, the youth movement was regarded as a representative of this social middle class, and the government understood that this movement had a potential to mobilize the middle class against the government. Therefore, the government did its best to destroy this genuine rise of the local youth in order to prevent them from promoting free thinking among the social middle class citizens.

\section{The Impact}

The impact of the youth was multidimensional. In politics it returned discussions over ideologies and to some extent changed monotone discussions around ethnic identity. It created very small number liberal-minded youth. It also revived the left, which seemed dead after the collapse of the Soviet Union. Young intellectuals managed to rise genuine interest in Eurocentric left and American way of liberalism. The youth found out more about classic liberal ideas and authors like David Smith, Karl Popper, Milton Friedman, Slavoj Žižek became known in a narrow circle. Interest in philosophy promoted by western or Turkish educated youth seriously challenged irrelevant attitude towards philosophy caused by boring soviet teachings of this field.

One of the main revelations was the fact that secular traditions did not fade away with the fall of the Soviet Union. Indeed, secularism even attracted followers among younger generations. Through 1990s and early 2000s, while traditional secular opposition failed to achieve its goals and the government continued to squeeze public sphere for independent voices as well as destroy democratic institutions such as free media and independent judiciary, there was a fear of rising Islam. Since the fall of the Soviet Union, some people expected that 
religiosity and political Islam will replace the seculars as the main alternative to the authoritarian regime. However, the case of Rafig Tagi gave us enough reason to assume that it was a doubtful conclusion. The assassination of AYO member Rafig Tagi, still unresolved, caused serious standoff between seculars and religious activists. Tagi was the fiercest critics of Islam and attracted religious proclamation from Iranian ayatollahs who condemned his writings. The refusal by the religious leaders of Azerbaijan to rise for 1 min silence to commemorate Tagi's memory caused an outrage among secular writers and journalists as well as secular public. In fact, vocal religious activists were silenced by the public outrage fomented by secular writers and journalists.

This youth awakening initiated some visible changes in general culture and behavior as well. In a conservative Azerbaijani society, it was rear to see young men and woman socializing together in public sphere like coffee houses or chaykhana. However, this awakening of youth activists, which called themselves Public Sektor (consisted of opposition-minded individuals), changed this tradition and popularized this attitude at least in downtown Baku. Activist women broke taboos and started going to chaykhanas (local traditional coffee houses) alone or with men. This attempt to the emancipation of women even popularized western style parties among a narrow circle of youth. Until then in Azerbaijan, a common way of going to restaurants was to go to private cabins. Currently attending public venues became a trend in downtown areas of Baku and youth activism described above significantly contributed to this relatively new development. Discussions over shorts for men, which were quite unusual and unappreciated by local people and officials, caused long discussions as well. Although still the vast majority of Azerbaijani men prefer trousers in hot summer days, at least discrimination against those wearing shorts has been diminished over the years. While it is hard to elaborate the reasons behind these changing attitudes of the people, it is clear that public discussions initiated by the activist youth played a significant role in this transformation.

Youth private theaters like Oda (Room) and Osa (Stick) (this one included disabled individuals as actors) were among the most successful initiatives. Forgotten cinemas and theatres, which became obscure after the fall of the Soviet Union, were popularized once more by the youth activism. "Sing for Democracy" and "Art or Democracy" campaigns launched by human rights activist Rasul Jafarov used music and art to turn attention to human rights abuses in Azerbaijan (ESI 2015). The first campaign even managed to attract Swedish singer Loreen, the winner of the Eurovision Song Contest held in Baku in 2012, who met with Jafarov and supported his cause (HRW 2012).

One of the main impacts was the changing attitude of the public with regards to females who decided to study abroad. Until the early 2000s, families usually 
did not consider this option at all because marriage of these girls in the future could be problematic due to the negative attitude of the public towards females who lived abroad alone. However, the emphasis of the youth activists on personal development and education, especially the state scholarship program which was accepted as a result of the youth activism normalized the view that girls too can study abroad.

In traditional Azerbaijani society, historically youth remained materially dependent on their families long after graduating from schools or universities. During this activation, however, the idea of leaving families became a new phenomenon. In a sense, activism contributed to the independence of youth as well. Moreover, the era of internet and mobile phones contributed to the rise of authority of Azerbaijani youth in their traditional and conservative families. Generally, old and mid age generation of Azerbaijanis were to slow to adapt to the new era of electronics and became dependent on the knowledge of youth. Furthermore, in a country where public sphere, television stations, and radios are under strict control of the oppressive government, the youth increased their influence in families due to their better access to alternative information via internet and technologies. Young people became primary information and knowledge holders in the traditional society. Youth also developed into the most active segment of the society in regard with political and social activism.

The most important achievement of the youth activism, in our view, was that the government eventually opened up some space for independent activity of the youth in one of the central districts of downtown Baku. Flourishing cafes and bars with live jazz music, theaters, and book stores created a vibrant life in the city center. Lured by the government or not, the majority of these small enterprises are launched by the active youth who one way or another were participants of the aforementioned independent or opposition minded organizations.

\section{The Reaction of the Government}

The government reaction to these activities of youth was multidimensional. There is no doubt that imprisonment and various kinds of intimidation were the primary tools employed by the oppressive, authoritarian regime. However, it seems the government understood that by oppression alone it would be very difficult to contain the whole process for a long time. In this regard, the most interesting fact was that among the other oppressive measures, the government hijacked this trend of youth activism by accepting methods and external appearances of these initiatives such as seminars and public talks while denying or neutralizing its content. 
There are many cases which can prove the statement above. For example, in order to attract youth and to prevent them from joining aforementioned opposition and independent youth activism the government promoted İroli (Forward) Youth Movement which was the continuation of the so-called National Council of Youth Organizations (NCYO), a pro-government group that operated since mid-1990s and successfully mobilized youth behind the ruling party. And the idea of İroli was initiated by the NCYO as well. With the initiative of the NCYO, National Youth day was created and annually commemorated by the government. Some activists of this organization reached high government positions: the best examples would be Intigam Aliyev, who became the deputy of the Minister of the Youth and Sport; Elnur Aslanov, who was appointed to lead one of the branches of the Presidential Administration; Elshad Iganderov, who was appointed the head of the Committee for Work with Religious Associations; Farhad Mehdiyev, who was appointed the head of The Center for Strategic Studies under the President of the Republic of Azerbaijan; Azay Guliyev, who was appointed as head of the government ministry responsible for work with the non-government organizations.

Under patronage of Elnur Aslanov, İroli started to rise as a result of some attractive projects. Another interesting fact about İrəli was that some of its activists, including the head of the organization Jeyhun Osmanli, were graduates of Gülen schools. However, it seems that despite spending lots of funds for its projects and initiatives, İrəli was failing to compete with the independent youth initiatives. And in 2014, for still debated reasons the government's favor towards İroli suddenly and drastically changed. Elnur Aslanov and Elshad Iganderov were fired. Suddenly İroli became an obscure organization. Moreover, Rauf Mardiyev, the chairman of İroli between 2012 and 2014, moved to the United States. It is assumed that after the destruction of all independent youth movements, the government did not need İrali anymore. Since then the government started to strengthen the ruling party's youth branch and the so called Student Unions in the universities which operate as unofficial branches of the ruling party.

However, the most important initiative of the government to attract youth became Yarat (Create) project, which is directly connected to the ruling family. There is no doubt that with more access to the government funds, Yarat proved to be more successful and attractive in comparison with İrəli. The main advantage of Yarat was its connection to the ruling family and as such the career opportunities it could provide, material incentives and glamour appeased the elitist desires of Azerbaijani youth. Elitism, despite its negative connotations, has always been driving force behind many changes in Azerbaijani society. The most interesting episode in Yarat's activities was the fact that in some instances in order to attract 
young people, it employed both appearances and narratives of independent and oppositional organizations it competed with. For instance, in one of the public lectures, which was organized by Yarat in style of AFU, the former used logos of the latter while designing promotional videos of its own lectures.

Even more interesting was the joining of Yarat to public opposition against some of the government policies. For example, in 2014, the government destroyed one of the historical districts in downtown Baku called "Sovetski" (built before the Soviet times during the first oil boom at the turn of the twentieth century) to clear space for its construction projects. Yarat held several expositions about this place in European capitals (Azertac 2014). In addition, the patron of Yarat Nargiz Pashayeva, who is sister of the first lady, signed a petition denouncing the destruction of historical buildings in Baku (Miq 2016). Eventually, despite the complete destruction of Sovetski district, the government decided to carry out restoration works in another historical district of Baku which currently hosts the vibrant youth life and enterprises discussed above. There were some other activities of Yarat with similar connotations, such as exhibitions called "300 words or resistance" (Trend 2016) an exhibition held in Heydar Aliyev Center, named after the late president and father of current president of Azerbaijan, about imprisoned poets around the world (Tripathi 2018) while the Azeri government itself has arrested several poets throughout years.

In some other cases, the protests force the government to dismiss some high ranking officials. For instance, after a few months of youth protests against non-combat death of conscripts in 2013, defense minister Safar Abiyev was dismissed in October of the same year (Sumerinli 2013). Moreover, head of the executive power of Ismayilli district was dismissed after the riots in that region (Geybullayeva 2013).

As it was mentioned above, one of the methods employed by the government was luring opposition-minded activists with material incentives. A prominent viner Huseyn Azizioglu, who ridiculed with some local traditions and officials in his highly popular short satiric videos, switched sides. Although after this drastic turnaround he lost his popularity among the opposition-minded individuals, he is still popular among the young people at large. Murad Kohnagala, one of the four founders of AYO, later became a fierce critic of the opposition and the Western countries. He met with Anar Rzayev, the chairman of AYB, to confess that he was wrong about him. Also, he wrote a letter to President Ilham Aliyev in order to receive a free apartment from the government (Böyükçöl 2016; Telamnqızı 2017). Another AYO member, Aqshin Yenisey, who was known as a critic of the government and AYB, became an editor of the pro-government website 1937.az and the online channel APA TV (Qafqazinfo 2013; Modern 2015). And Qan Turalı, 
one of the leading figures of AYO, was "neutralized" after he started to work with Kulis.az, a pro-government website, and due to this "switch", he was criticized by his colleagues Seymur Baycan and Elnur Astanbayli (Danyeri 2011; Elitar. info 2013). One of the most interesting cases in this regard was the case of inclusive Osa ("Handstick") theatre. In a time when theatres completely lost popularity after the fall of the USSR, creation of private theatres was one of the most interesting engagements of active youth. This initiative of the youth forced the government to pay more attention to the popularization of the state theatres as competitors for new youth interests. And in general, the government was quite successful in achieving its goals. Theatre attendance rose sharply. Moreover, the Osa theater, which was known for its critical approach to the authoritarian rule and conservative backward traits of the society and which managed to attract public attention to the problems of the persons with disabilities, eventually switched sides and accepted the patronage of the government; thus, opened its ways to the stages of the state theatres.

Another initiative of the government was to create an impression that it brings the open-minded youth to the administration. Several young people were appointed to ministerial positions or other high ranking positions in Presidential Administration, mainly as aides and counsellors of vice-president and the first lady Mehriban Aliyeva.

However, we should sadly note that general political environment, that is, the lack of public sphere for open public and political discussions and rampant corruption forced many youths to leave Azerbaijan and seek better conditions in other countries. Brain drain became a very serious issue which we guess will be felt in midterm perspective. Compared to the years discussed in this article, in the last few years, the activism of the new opposition declined sharply. Many of the key figures left the country and the government repressions created a general despair. In a sense, the new opposition was forced to start from the scratch. Due to the current stagnation among the young people in terms of social and political activism, it is difficult to predict future developments within the new opposition.

In late 2014, sharp decline in fuel prices caused the deep crisis in Azerbaijani economy, which is heavily dependent on the oil exports. The national currency was devaluated twice in 2015, dozens of banks failed (U.S. Department of State 2018). This crisis also boosted the activism to certain extent and forced the government to announce multiple development programs and its intention to concentrate efforts on the diversification of economy. Nevertheless, only minor changes followed these declarations and major liberalization of economy has yet to be happened. The only filed where some real positive changes have been implemented was the tourism industry. As a result of them, the country witnessed big 
flow of tourists in comparison with the previous years. Moreover, it seems that current rebound in oil prices raised the confidence of the government.

In 2018 there were another presidential elections and incumbent Aliyev was elected for the fourth term and according to the latest changes to the Constitution, president's term in office extended from five to seven years. However, the Armenian Velvet Revolution created serious discomfort for increasingly authoritarian regime in Azerbaijan. For despite the enmity between two countries, Azerbaijani social media users were expressing their respect to the Armenian people in their successful attempt of overthrowing Armenian anti-democratic government and the Azerbaijani authorities feared that democratic developments in the neighboring country can be an inspiration for Azerbaijanis. In addition, strengthening political Shia Islam in the country along with continuing discontent in the society adds to the unpredictability of future developments.

\section{Discussion}

The referendum of 2009 which lifted the two term limit on presidential power was another milestone in transformation of Azerbaijan into a consolidated authoritarianism. However, the next few years the government faced the youth movement which attracted sympathies of middle class and, thus, had a potential to revert the "gains" of the government. Yet, the authorities resorted to unprecedented large scale repressions, which halted the potential transformation. Subsequently, in 2016, the government held another referendum that extended presidential years in power from 5 to 7 years. Moreover, this referendum introduced new positions of vice-presidents in the hierarchy of the state administration and the president appointed his spouse the first vice-president. It seems that the republic has successfully been transformed into an informal monarchy.

Seeking options for immigration one way or another became an emerging trend as a response of youth to this tightening of regime. The rise of secular intellectual youth was replaced with its exodus. Unfortunately, the destruction of this genuine youth awakening by repressions to some extent re-opened the frightening possibilities for political Islam to replace the secular-democratic forces as the main alternative to Azerbaijani authoritarianism.

Still, the youth movement did stimulate some minor positive changes. It forced the government to adjust its policies and to appease the discontent of youth by applying some cosmetic as well as genuine changes and opening up some space for the youth activities. One of the most important achievements of the youth movement was that under the pressure of youth awakening 
the government eventually responded to the public concerns and significantly reduced wide-spread bribery practices in universities where these practices flourished for decades. We also conclude that the youth movement has genuinely contributed to cultural modernization by questioning some conservative traits and taboos of the society. It stimulated some positive trends, including revival of interest in reading and, thus, contributed to the re-birth of publishing, translation, and bookseller businesses. In addition, it seems that the repressions which were extensively covered in international media and seriously damaged the image of Azerbaijani authorities in the international arena have also forced the authorities to seek alternative ways of re-engagement with the Western powers in order to soften the possible repercussions of its heavy-handed domestic policies.

Nevertheless, we should acknowledge that during the short period between the awakening and the repressions the impact of the youth movement was limited in scope, and it mobilized relatively small portion of the general population. Even AFU, which was the most popular place for public discussions, attracted just four thousand new people in four years and a small part of those participants became socially or politically active. Yet, indeed, within this Public Sektor young activists became the driving force and the new faces of resistance.

Finally, the new opposition was not free from its own serious shortcomings. Youth activists were too unprepared and unexperienced to succeed in promotion of democratic values. One of the most crucial deficiencies of the new opposition was the lack of ideological unity. Newly established youth movements did neither accept any ideology, nor successfully managed to teach political ideologies in depth to young people. In some cases, respected representatives of the Sektor demonstrated disappointing inconsistency and controversy. The lack of respect and tolerance of the new opposition members towards "others" as well as their refusal to increase their expertise in the matters they vowed to promote have also negatively impacted many positive contributions of the new opposition.

\section{References}

2012. Eurovision Winner Loreen Met with Human Rights Defenders. Human Rights House Foundation (blog). https://humanrightshouse.org/articles/eurovision-winner-loreen-metwith-human-rights-defenders/. Accessed 19 Dec 2018.

2015. Rasul Jafarov - Azerbaijan - ESI. https://www.esiweb.org/index.php?lang=en\&id= 577. Accessed 19 Dec 2018. 
AFU: Azad Fikir Universiteti - Posts. (2013). Web, Facebook. https://www.facebook.com/ azadfikir/posts/10151571731579393?_xts__[0]=68.ARB65wiBLM3I8DAZZyppJEEc9kbMzJFcIZHgImrTUTbQOVHyMpnvjxM7YFPkGRg_jbiRHrLQNafYy-0d4yCc3K646ELNH8-iXb7_hXoih2V0Et8V_g2mM8qI5UhbTIbx46u9ggSSOb19w51dGOPonqWVehic9ypBwEo7lBWWofBjiDkS2-PM_PU\&_tn__=-R. Accessed 19 Dec 2018.

Amnesty International. (2015). Azerbaijan: The repression games. The voices you won't hear at the first European Games. Amnesty International. http://www.amnesty.eu/content/assets/Reports_and_Briefings_2015/Azerbaijan-The_Repression_Games.pdf. Accessed 19 Dec 2018.

Asadov, R. (2009) „Xalq Dövlət Üçün Yox, Dövlət Xalq Üçündür.“ OL! Bloqu (blog). http://ol-az.blogspot.com/2009/10/xalq-dovlt-ucun-yox-dovlt-xalq-ucundur.html.

Azertac. (2014). YARAT to participate in VIENNAFAIR the new contemporary. Azertag. https://azertag.az/en/xeber/YARAT_to_participate_in_VIENNAFAIR_The_New_Contemporary-799326. Accessed 19 Dec 2018.

BBG. (2018). BBG deplores decision by Azerbaijan authorities to take VOA, RFE/RL and BBC Off FM and television. BBG. https://www.bbg.gov/2008/12/30/bbg-deploresdecision-by-azerbaijan-authorities-to-take-voa-rferl-and-bbc-off-fm-and-television/. Accessed 19 Dec 2018.

Böyükçöl, K. (2016). Murad Köhnəqala: 'Prezidentə müraciət eləmişəm’ - MÜSAHİBӘ. Teleqraf.com. https://teleqraf.com/news/art/114670.html. Accessed 19 Dec 2018.

Dalğa. (2005) „Bəyannamə.“ Dalğa Gənclər Hərəkatı (blog). http://dalga-gh.blogspot. com/2005/12/byannam.html.

Danyeri, R. (2011). Vicdansizlığın dərəcəsinə bax ki, Qan Turalı satıldı! Xural. https:// www.xural.com/vicdansizligin-d\%c9\%99r\%c9\%99c\%c9\%99sin\%c9\%99-bax-ki-qanturali-satildi/. Accessed 19 Dec 2018.

Democracy Monitor. (2007). Statement on the 'deteriorating situation with the freedom of expression in Azerbaijan' OSCE. Organization for Security and Co-operation in Europe. https://www.osce.org/odihr/27699. Accessed 19 Dec 2018.

de Waal, T. Azerbaijan's inconvenient prisoner. Carnegie Europe. http://carnegieeurope.eu/ strategiceurope/75406. Accessed 19 Dec 2018.

Elitar.info. (2013). Seymur Baycan: 'Qan Turalı şantaj olunub.' Mia.az. http://www.mia.az/ w39693/Seymur_Baycan:_Qan_Tural\%C4\%B1_\%C5\%9Fantaj_olunub/. Accessed 19 Dec 2018.

ESI - European Stability Initiative. (2011). Generation Facebook in Baku. Adnan, Emin and the future of dissent in Azerbaijan - Azerbaijan - Reports - ESI. https://www.esiweb.org/index.php?lang=en\&id=156\&document_ID=128. Accessed 19 Dec 2018.

Fukuyama, F. (2014). Political order and political decay: From the industrial revolution to the globalization of democracy (Unabridged edition). New York: Brilliance Audio.

Geybullayeva, A. (2013). Riots and protests in Azerbaijan. Osservatorio Balcani e Caucaso. https://www.balcanicaucaso.org/eng/Areas/Azerbaijan/Riots-and-protests-in-Azerbaijan-130268. Accessed 19 Dec 2018.

Heinrich, A. (2011). The formal political system in Azerbaijan. Caucasus Analytical Digest, 24, 2-5. 
HRW. (2016). Azerbaijan: Unprecedented government crackdown. Human Rights Watch. https://www.hrw.org/news/2016/01/27/azerbaijan-unprecedented-government-crackdown. Accessed 19 Dec 2018.

IMS. (2015). A year of unprecedented repression in Azerbaijan. International Media Support (blog). https://www.mediasupport.org/anniversary-human-rights-defenders-arrestmarks-one-year-unprecedented-repression-azerbaijan/. Accessed 19 Dec 2018.

IRFS. (2009). IRFS I Emin Milli receives 2,5 years imprisonment and Adnan Hajizade receives 2 years imprisonment. https://www.irfs.org/news-feed/emin-milli-receives25-years-imprisonment-and-adnan-hajizade-receives-2-years-imprisonment/. Accessed 19 Dec 2018.

Isler Beguin, M. A. (2008). Presidential elections in Azerbaijan: Election observation delegation 13-16 October 2008. European Parliament.

Kassa, G. (2012). How To plan a revolution? (Azerbaijan). Web, YouTube. https://www. youtube.com/watch?v=LYQ_PvooIFY. Accessed 19 Dec 2018.

Mehtiyeva, A. (2009). Loner shoots 13 dead at Azerbaijan college. Reuters. https://www. reuters.com/article/us-azerbaijan-shooting/at-least-10-dead-in-azeri-college-shootingreport-idUSTRE53T1NF20090430. Accessed 19 Dec 2018.

Milli, E. (2009). Hakim Dairələrdə Başa Düşürlər Ki, Hansısa Gənclər Qrupu Gələcəkdə Böyük Bir Hərəkata Çevrilə Bilər. OL! Bloqu (blog). http://ol-az.blogspot. com/2009/05/hakim-dairlrd-basa-dusurlr-ki-hanssa.html. Accessed 19 Dec 2018.

Miq. (2016). Nərgiz Paşayeva Da Bakıda Tarixi Binaların Sökülməsinə Qarşı Çıxdı. Miq. AZ Azərbaycanda Özəl Xəbərlər, Araşdırmalar, Təhlillər və Müsahibələrin Tək Ünvanı. http://miq.az/az/nergiz-pasayeva-da-bakida-tarixi-binalarin-skulmesine-qarsi-cixdi/. Accessed 19 Dec 2018.

Modern. (2015). Aqşin Yenisey APA TV-yə redaktor aparıldı. Modern.az. http://modern.az/ az/news/72320. Accessed 19 Dec 2018.

Muradova, M. (2013). Azerbaijani authorities close opposition university. http://www.cacianalyst.org/publications/field-reports/item/12707-azerbaijani-authorities-close-opposition-university.html. Accessed 19 Dec 2018.

OL! Blog. Gül Bayramı Günü Gənclərin Etirazının Xronologiyası. OL! Bloqu (blog). http://ol-az.blogspot.com/2009/05/10-may-gul-bayram-gunu-gnclrin-etiraznn.html. Accessed 4 Sept 2018.

OL! FAQ. (2006). Frequently Asked Questions. OL! Bloqu (blog). http://ol-az.blogspot. com/2009/01/frequently-asked-questions.html. Accessed 19 Dec 2018.

OL! Manifesto. "OL!” Azerbaijan Youth movement manifesto. OL! Bloqu (blog). http:// ol-az.blogspot.com/2006/06/ol-azerbaijan-youth-movement-manifesto.html Accessed 19 Dec 2018.

OL! Media. (2008). Eşşəklə (Esel Heinz) Müsahibe - QHT Qanunu Haqqında Şok Açıqlamalar. Web, YouTube. https://www.youtube.com/watch?v=Aaecvg7xCIk. Accessed 19 Dec 2018.

OL! Media. (2009). „Gül Bayramı: Müsahibə N4 - YouTube.“ https://www.youtube.com/ watch? $\mathrm{v}=$ RsLxR4T1ErY.

OSCE. (2013). OSCE/ODIHR final report on Azerbaijan presidential election recommends measures to bring elections in line with OSCE commitments, international standards. OSCE. Organization for Security and Co-operation in Europe https://www.osce.org/ odihr/elections/110030. Accessed 19 Dec 2018. 
Pearce, K., \& Guliyev, F. (2015). Digital knives are still knives: The Affordances of social media for a repressed opposition against an entrenched authoritarian regime in Azerbaijan. SSRN Scholarly Paper. Rochester, NY: Social Science Research Network. https:// papers.ssrn.com/abstract $=2886692$.

Qafazzinfo. (2013). Aqşin Yenisey baş redaktor oldu. Qafqazinfo. http://qafqazinfo.az/ news/detail/aqsin-yenisey-bas-redaktor-oldu-65879. Accessed 19 Dec 2018.

Qaraca, R. (2018). Zülmətdə Bir Alatoran. Baku: Alatoran.

RWB. (2011). Journalist critical of Islam dies four days after being stabbed by attacker. Reporters without Borders. RSF. https://rsf.org/en/news/journalist-critical-islam-diesfour-days-after-being-stabbed-attacker. Accessed 19 Dec 2018.

Salamli, V. (2006). OL'un Yaranma 'Mif'I. OL! Bloqu (blog). http://ol-az.blogspot. com/2009/02/ol-yaranmas-mifi.html. Accessed 19 Dec 2018.

Sumerinli, J. (2013). Shake-up at Azerbaijan's defence ministry. Institute for War and Peace Reporting. https://iwpr.net/global-voices/shake-azerbaijans-defence-ministry. Accessed 19 Dec 2018.

Telmanqızı, S. (2017). 'Onların heç biri Anarın tayı deyil' - Köhnəqala ilə skandal müsahibə (Fotolar, video). http://musavat.com/news/onlarin-hec-biri-anarin-tayi-deyilkohneqala-ile-skandal-musahibe-fotolar-video_453646.html. Accessed 19 Dec 2018.

Trend. (2016). Müqavimət Haqqında 300 Söz. Trend.Az. https://az.trend.az/tags/37105/. Accessed 19 Dec 2018.

Tripathi, S. (2018). A different kind of poets' society. livemint.com. https://www.livemint. com/Leisure/Kf8qM6y3RSNDld4WFFfhZO/A-different-kind-of-poets-society.html. Accessed 19 Dec 2018.

U.S. Department of State. (2018). Azerbaijan: 2018 investment climate statements. Bureau of Economic and Business Affairs. http://www.state.gov/e/eb/rls/othr/ics/2018/ eur/281559.htm. Accessed 19 Dec 2018. 